\title{
Steroidogenic enzymes mRNA expression profile and steroids production in bovine theca cells cultured in vitro and stimulated with angiotensin II
}

\author{
Perfil de expressão de RNAm de enzimas esteroidogênicas e produção de esteroides a partir de \\ células da teca bovina cultivadas in vitro e estimuladas por Angiotensina II
}

\author{
Melânia Lazzari Rigo ${ }^{I}$ Andressa Minussi Pereira Dau ${ }^{I}$ Werner Giehl Glanzner ${ }^{I}$ Manoel Martins ${ }^{I I}$ \\ Renato Zanella ${ }^{\text {II }}$ Tiele Medianeira RizzettiI ${ }^{I}$ Fabio Vasconcellos Comim I, III \\ Paulo Bayard Dias Gonçalves ${ }^{I}$
}

\begin{abstract}
The main objective of this study was to detect the steroidogenic effects of Ang II in bovine theca cells in vitro. Bovine theca cells were obtained from follicles (larger than $10 \mathrm{~mm}$ of diameter) collected from a local abattoir and submitted to different treatments in a sequence of experiments. In experiment 1 , CYP17A1 $\mathrm{mRNA}$ profile was evaluated in LH- $\left(10 \mathrm{ng} \mathrm{ml}^{-1}\right)$ and Ang II-treated $(0.1 \mu \mathrm{M})$ theca cells. In experiment 2, a dose-response

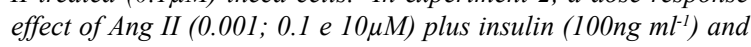
LH (100ng $\left.\mathrm{ml}^{-1}\right)$ was evaluated on steroidogenesis of bovine theca cells. Experiment 3 explored the effects of saralasin (an antagonist of Ang II receptors) on steroid production and steroidogenic enzymes regulation in theca cells. After 24 hours, culture media from experiments 2 and 3 was collected to evaluate testosterone and androstenedione levels by High-Performance Liquid Chromatography. In parallel, $m R N A$ levels of key steroidogenic enzymes (HSD3B2, CYP11A1, CYP17A1) and STAR were assessed by RT-PCR. There was no difference in testosterone and androstenedione production between treated and controls groups, as well as in mRNA levels of the evaluated genes. In conclusion, the results suggest that Ang II does not regulate steroidogenesis in bovine theca cells.
\end{abstract}

Key words: $R A S, L H$, steroidogenesis, ovary.

\section{RESUMO}

$O$ objetivo deste trabalho foi verificar o efeito da Angiotensina II (Ang II) sobre a esteroidogenese nas células da teca bovina, cultivadas in vitro. Para isso, células da teca bovina foram obtidas de folículos maiores que $10 \mathrm{~mm}$ de diâmetro de ovários oriundos de abatedouro e submetidas a diferentes tratamentos em uma sequencia de experimentos. No experimento 1, o perfil de expressão do RNAm de CYP17A1 foi avaliado nas células da teca em resposta ao LH (10ng $\left.\mathrm{ml}^{-1}\right)$ elou Ang II $(0,1 \mu \mathrm{M})$ em diferentes momentos de tratamento. No experimento 2, foi investigado o

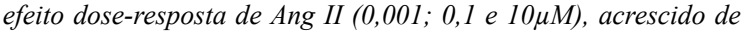
insulina (100ng $\mathrm{ml}^{-1}$ ) e LH (100ng $\mathrm{ml}$ ) sobre a esteroidogênese nas células da teca bovina. O experimento 3 explorou os possiveis efeitos da Ang II por meio do tratamento de células da teca com saralasina (antagonista dos receptores da Ang II). Após 24 horas, nos experimentos 2 e 3, o meio de cultura foi coletado e avaliado quanto aos níveis de testosterona e androstenediona pela técnica de HPLC. Em paralelo, a expressão gênica de enzimas-chave da esteroidogênese (HSD3B2, CYP11A1, CYP17A1) e STAR foi avaliada por $q R T-P C R$. Não se observou diferença na produção de testosterona e androstenediona entre controle e grupos tratados, bem como, na expressão do RNAm para os genes estudados. Em conclusão, nossos resultados não demonstraram um papel da Ang II sobre a esteroidogenese nas células da teca bovina.

Palavra-chave: $R A S, L H$, esteroidogênese, ovário.

\section{INTRODUCTION}

Synthesis of androgens occurs in response of a LH peak (YOUNG \& MCNEILLY, 2010). This process is initiated by the Steroidogenic acute regulatory protein $(S T A R)$, which transports cholesterol into mitochondria of theca cells. Inside the mitochondria, cholesterol is converted to pregnolone by the action of P450scc enzyme (CYP11A1). Pregnolone is transported out of the cytosol and is converted to progesterone by the enzyme 3 $\beta$-hidroxiesteroide desidrogenase (HDS3B2). Progesterone is converted to $17 \alpha$-hidroxiprogesterone

\footnotetext{
'Laboratório de Biotecnologia e Reprodução Animal (BioRep), Universidade Federal de Santa Maria (UFSM) Santa Maria, RS, Brasil.

"Laboratório de Analise de Resíduos de Pesticidas, UFSM, Santa Maria, RS, Brasil.

IIIDepartamento de Clínica Médica, Curso de Medicina, UFSM, 97105-900, Santa Maria, RS, Brasil. E-mail: fabio.comim@bol.com.br.

Corresponding author.
} 
by the enzyme $17 \alpha$-hidroxilase (CYP17A1). The main hormone produced from $17 \alpha$-hidroxiprogesterone is androstenedione, which can be converted to testosterone by the isoenzyme $17 \beta$-hidroxisteroide deidrogenase (HSD17B) in theca cells or to estrone by aromatase (CYP19A1) in granulosa cells. In general, theca cells express the crucial enzymes responsible for the conversion of cholesterol to androgens, otherwise, the conversion of androgens to estradiol happens in granulosa cells.

Although there is a complex network of genes involved in steroidogenesis, the majority of them are not clearly elucidated in this process. There is evidence relating the Renin Angiotensin System (RAS) with steroidogenesis since 1995, when it was first demonstrated that angiotensin II (Ang II) could act on steroid production in both theca and granulosa cells of rabbits (FERAL et al., 1995). In bovine, it has also been shown that Ang II can affect steroidogenesis, mainly in granulosa cells. Ang II participates in the synthesis of estrogen through CYP19A1 during follicular deviation (FERREIRA et al., 2011b). However, it did not stimulate progesterone production and LH-induced STAR expression (PORTELA et al., 2011). In theca cells, there was no difference in mRNA expression for CYP17A1, HSD3B2 and STAR between dominant follicles treated with saralasin or vehicle during follicular deviation (FERREIRA et al., 2011a). During the preovulatory period, variations in AGTR2 mRNA levels were shown in theca but not in granulosa cells after the administration of analogue GnRH (SIQUEIRA et al., 2012). Nevertheless, it is still not clear if Ang II stimulates steroidogenesis in bovine theca cells treated with LH.

To better understand the role of Ang II on the regulation of steroidogenesis in theca cells, this study evaluated the function of Ang II alone or in association with LH on the mRNA profile of steroidogenic enzymes and steroid production. To achieve this objective, a validated in vitro theca cells cultures system was used (SCHREIBER et al., 2012).

\section{MATERIAL AND METHODS}

All reagents were purchased from Sigma-Aldrich unless otherwise mentioned.

Cell Isolation, culture and treatment

Theca cells were obtained from ovaries of non-pregnant adult cows collected in a local slaughterhouse. The ovaries were transported in thermal compartments $\left(30^{\circ} \mathrm{C}\right)$ with saline solution ( $\mathrm{NaCl} 0.9 \%)$ supplemented with penicillin (100UI $\left.\mathrm{mL}^{-1}\right)$ and streptomycin $\left(50 \mu 1 \mathrm{~mL}^{-1}\right)$. Theca cells were harvested no longer than 3 hours after the collection of the ovaries. Cells were isolated from follicles larger than $10 \mathrm{~mm}$ that were apparently healthy, i.e. those showing good vascularization, translucid follicular fluid and absence of an active $(>1 \mathrm{~cm})$ corpus luteum, thus avoiding the use of atretic follicles. The internal walls of the follicles were rinsed in PBS to remove granulosa cells. The collected theca tissues were digested in a collagenase solution $\left(1 \mathrm{mg} \mathrm{mL}^{-1}\right)$ for cell separation and the obtained cells were seeded in $60 \mathrm{~mm}$ culture plates. Cells were cultured for 48 hours in a basic medium: (DMEM/F12 supplemented with $10 \%$ fetal bovine serum (FBS), $1 \mu \mathrm{g} \mathrm{mL}^{-1}$ transferrin, $1 \mathrm{ng} / \mathrm{mL}$ selenium, 100UI $\mathrm{mL}^{-1}$ penicillin, $100 \mu \mathrm{g}$

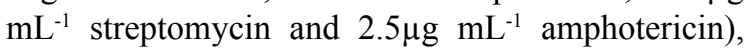
at $38.5^{\circ} \mathrm{C}$ and $5 \%$ of $\mathrm{CO}_{2}$ as described previously (COMIM et al., 2013; SCHREIBER et al., 2012). After this period, the cells used in experiment 1 were trypsinized and seeded $\left(2 \times 10^{5}\right.$ cells well $\left.{ }^{-1}\right)$ in 4-well culture plates (Thermo Scientific). In experiments 2 and 3 , cells were seeded in 96-well plates (Corning) with a concentration of $3 \times 10^{4}$ cells well ${ }^{-1}$ and cultured under the same culture conditions for 24 hours. The cells were then treated in a final volume of $400 \mu \mathrm{l}$ (experiment 1) and $150 \mu 1$ (experiments 2 and 3) using the same basic medium in the absence of FBS. In experiment 1 , bovine theca cells were cultured for $30 \mathrm{~min}, 1,3,6,12$ or 24 hours in the presence of Ang II and LH to evaluate the mRNA expression profile of CYP17A1. The treatments were: 1 - Negative control (only medium); 2 - LH (10ng $\left.\mathrm{mL}^{-1}\right) ; 3$ - LH (10ng $\left.\mathrm{mL}^{-1}\right)+$ Ang II $(0.1 \mu \mathrm{M})$; and 4 - Ang II $(0.1 \mu \mathrm{M})$. In experiment 2 , the objective was to verify a possible dose response effect of Ang II on mRNA levels of steroidogenic enzymes. To perform this experiment, cells were cultured in the presence of insulin (100ng $\mathrm{mL}^{-1}$ ) and the following groups were tested: 1 -Negative control; 2 - LH; 3 - LH + Ang II $(10 \mu \mathrm{M}) ; 4$ - LH + Ang II $(0.1 \mu \mathrm{M})$; and 5- LH + Ang II $(0.001 \mu \mathrm{M})$. Experiment 3 was conducted to investigate if Ang II role on bovine theca cells steroidogenesis cells is affected in the presence of an Ang II receptors antagonist (saralasin). The following treatments were tested: 1 - Negative control; 2 - Insulin (100ng mL $\left.\mathrm{m}^{-1}\right) ; 3$ - LH (100ng $\mathrm{mL}^{-1}$ ) + Insulin (100ng mL $\left.\mathrm{mL}^{-1}\right) ; 4$ - LH (100ng mL $\left.\mathrm{mL}^{-1}\right)+$ Insulin (100ng mL $\left.\mathrm{m}^{-1}\right)+$ Ang II $(0.1 \mu \mathrm{M}) ; 5$ - LH (100ng mL $\left.\mathrm{mL}^{-1}\right)$ + Insulin $\left(100 \mathrm{ng} \mathrm{mL}^{-1}\right)+$ Ang II $(0.1 \mu \mathrm{M})+$ Saralasin $(0.1 \mu \mathrm{M}) ; 6$ - Ang II $(0.1 \mu \mathrm{M}) ; 7$ - Ang II $(0.1 \mu \mathrm{M})+$ Saralasin $(0.1 \mu \mathrm{M})$; and 8 - LH (100ng $\left.\mathrm{mL}^{-1}\right)+$ Insulin $\left(100 \mathrm{ng} \mathrm{mL}^{-1}\right)+$ Saralasin $(0.1 \mu \mathrm{M})$. In experiments 2 and 3 , the culture media was collected after 24 hours of treatment to measure steroid production and cells were stored in Trizol $^{\circledR}$ (Invitrogen) for RNA 
extraction. All the experiments were performed in triplicate. The absence of CYP19A1 mRNA was used to verify the possible contamination with granulosa cells, and positive samples were eliminated from the study.

RNA extraction and quantification and reverse transcription

Total RNA was obtained using Trizol $^{\circledR} \quad$ according manufactures instructions. The quantification was performed using a spectrophotometer NanoDrop (ND1000 - Thermo Scientific) with a wavelength of $260 \mathrm{~nm}$. RNA integrity was assessed by electrophoresis in a $1.2 \%$ agarose gel stained with ethidium bromide. Purity was assessed through absorption rate OD260/OD280 and samples showing a value inferior to 1.8 were discarded. Total RNA $(1 \mu \mathrm{g})$ was treated with DNase (DNAse Amplification Grade I - Invitrogen) at $37^{\circ} \mathrm{C}$ during $5 \mathrm{~min}$ to digest any contaminating DNA. The reverse transcription reaction to cDNA was performed using the iScript cDNA Synthesis Kit ${ }^{\mathbb{B}}$ (BioRad) according to manufactures instructions.

\section{qRT-PCR}

The real time PCR to assess mRNA levels was performed in the Step One Plus termocycler (Applied Byossistems) using SYBR Green (Power SYBR Green PCR Master Mix - Life Technologies). After amplification, the melting curves were analyzed to verify the amplification of only one product. The relative mRNA expression was calculated based on the amplification of the reference gene GAPDH according to PFAFFL et al. (2001). The primers used for the amplification of CYP17A1 (sense: CCATCAGAGAAGTGCTCCGAAT and antisense: GCCAATGCTGGAGTCAATGA), CYP11A1 (sense: CTTGCACCTTTCTGGCTAGG and antisense: AAGGGGAAGAGGTAGGGTGA), HSD3B2 (sense: GCCCAACTCCTACAGGGAGAT and antisense: TTCAGAGCCCACCCATTAGCT) and STAR (sense: CCCAGCAGAAGGGTGTCATC and antisense: TGCGAGAGGACCTGGTTGAT) were based on previous studies (GASPERIN et al., 2012) and were synthetized by Invitrogen.

\section{Hormonal dosage through UHPLC-MS/MS}

The identification and quantification of androstenedione and testosterone were performed using Ultra High Performance Liquid CromatographyTandem Mass Spectrometry (UHPLC-MS/MS). For extract preparation, $200 \mu \mathrm{L}$ samples were diluted in acetonitrile until reaching $500 \mu \mathrm{L}$. This mixture was homogenized by vortexing and injected in the UHPLCMS/MS system. After that, an analytical solution (internal pattern) for androstenedione, testosterone and triphenylphosphate was added to the mixture to reach a final concentration of $100 \mathrm{ng} \mathrm{L}^{-1}$. This new mixture was once again injected in to the system. The results were calculated through the Pattern Addition and the triphenylphosphate pattern was used to verify during chromatography assay. The linearity and the detection limits of each analytic were verify through analytic solutions with concentrations ranging from 50 to $5000 \mathrm{ng} \mathrm{L}^{-1}$ injected in the UHPLC-MS/MS. Using the data obtained with dilutions, the calibration curves were obtained. The spectrophotometer was operated in the Selected Reaction Monitoring (SRM) mode, with two transitions for each analytic, one for quantification and the second for confirmation. The higher intensity transition corresponds to analytic quantification and the second higher transition corresponds to confirmation. The ionization mode used was Electrospray Ionization (ESI) in positive mode for androstenedione and testosterone, with column oven temperature at $40^{\circ} \mathrm{C}$, pressure of $15000 \mathrm{psi}$, capillary of $2.8 \mathrm{kV}$, desolvation temperature at $500^{\circ} \mathrm{C}$, gas flow $800 \mathrm{~L} \mathrm{~h}^{-1}$, collision gas flow (argon) of $0,15 \mathrm{~mL} \mathrm{~min}^{-1}$ and source temperature about $150^{\circ} \mathrm{C}$. The mobile phase used was compose of aqueous solution (solvent A), $0.05 \%$ of ammonium hydroxide and methanol (solvent B). A boiling gradient was used with $0.150 \mathrm{~mL} \mathrm{~min}^{-1}$ flow and an injection volume of $10 \mu \mathrm{L}$ and total running time of $5 \mathrm{~min}$.

\section{Statistical analysis}

Gene expression and hormonal synthesis data were analyzed comparing between treatments. The differences were tested by ANOVA and the differences found, tested by LSMEANS Student's $t$ between different treatments. All data were tested for normality and when necessary normalized through data ranking. Data analyses were performed using the $\mathrm{JPM}^{\circledR}$ software (SAS Institute). The results are expressed as mean \pm standard mean error and all the values were obtained from three individual and distinct replicates.

\section{RESULTS AND DISCUSSION}

Ang II alone or in the presence of $\mathrm{LH}$ in the concentration of $10 \mathrm{ng} \mathrm{mL}^{-1}$, the same concentration used by COMIM et al. (2013), did not increase mRNA levels of the steroidogenic enzyme CYP17A1 in cultured theca cells treated for $30 \mathrm{~min}$, 1-, 3-, 6-, 12- or 24-h (Figure 1A-F). STEWART et al.

Ciência Rural, v.45, n.4, abr, 2015. 


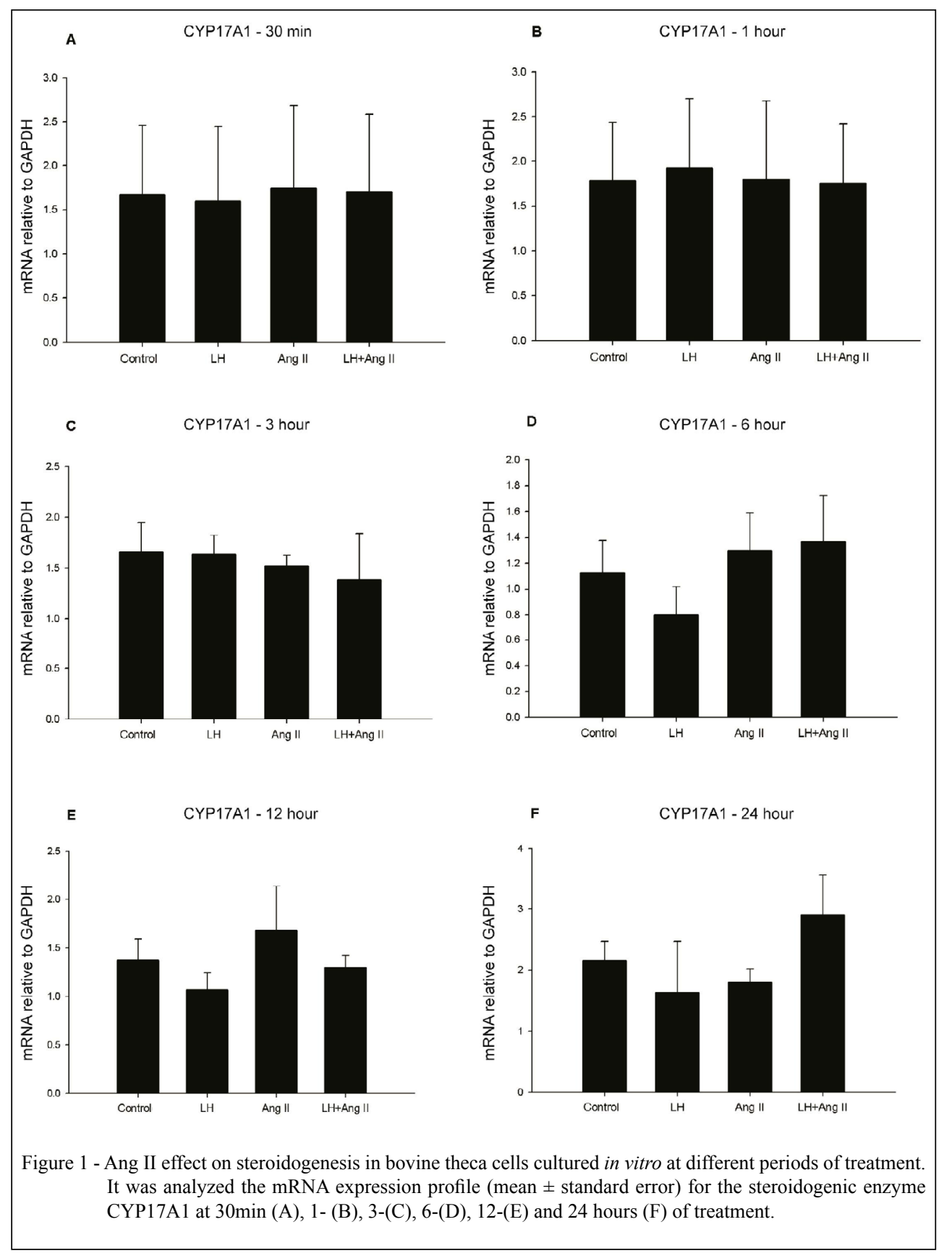

(1995) demonstrated an increase in androstenedione concentration after treatment with insulin, in a dose response manner $\left(1,10\right.$ e $\left.100 \mathrm{ng} \mathrm{ml}^{-1}\right)$, associated with $\mathrm{LH}(100 \mathrm{ng} / \mathrm{ml})$ in bovine theca cells cultured in vitro for 24 hours. Because of that, in experiments 2 and 3 , theca cells were treated with LH (100ng $\mathrm{mL}^{-1}$ ) and insulin (100ng $\left.\mathrm{mL}^{-1}\right)$. This experiment was performed to verify a possible stimulatory effect on mRNA expression of steroidogenic enzymes, as well as, on androstenedione and testosterone production according to the methodology proposed by COMIM et al. (2013) and SCHREIBER et al. (2012).

Angiotensin II, at the three different concentrations tested $(10 \mu \mathrm{M}, 0.1 \mu \mathrm{M}$ e $0.01 \mu \mathrm{M})$ in the presence of LH (100ng $\left.\mathrm{mL}^{-1}\right)$ and insulin (100ng $\mathrm{mL}^{-1}$; Figure $2 \mathrm{~A}-\mathrm{B}$ ), did not stimulate androstenedione and testosterone production in bovine theca cells. Nevertheless, previous studies in rabbit have demonstrated that Ang II can stimulate testosterone production in theca cells cultured in vitro and treated 

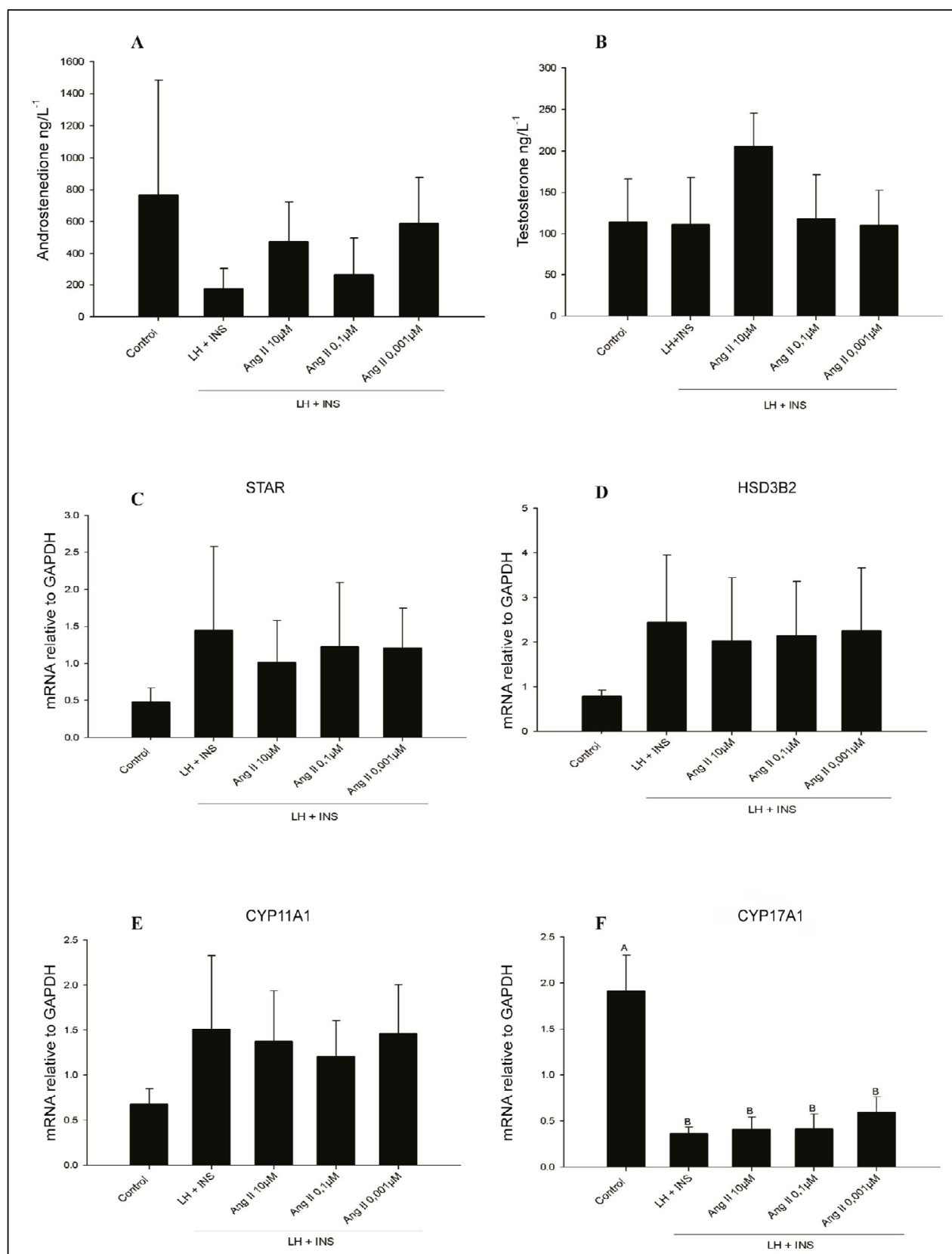

Figure 2 - Dose response effect of Ang II in steroidogenesis in bovine theca cells cultured in vitro, after 24 hours of treatment. Steroid measurements such as androstenedione (A) and testosterone (B) and mRNA expression for STAR (C), HSD3B2 (D), CYP11A1 (E) and CYP17A1 (F). The results are shown as mean \pm standard error.

with hCG (FERAL et al., 1995). These differences are likely due to a specie-specific factors since the RAS system is not uniform in mammals (GONÇALVES et al., 2012). In bovine, there was no effect of Ang II alone or in association with LH on androstenedione or testosterone synthesis in theca cells, neither on progesterone production induced by LH in granulosa cells (PORTELA et al., 2011). Additionally, it was observed a significant decrease in mRNA abundance for the enzyme CYP19A1 in granulosa cells of dominant follicles after intrafollicular injection of saralasin (FERREIRA et al., 2011a). Although it seems that Ang II does not stimulate the synthesis of androstenedione and testosterone in theca cells, and 
progesterone in granulosa cells, it might have a role in estrogen prodution in granulosa cells.

The theca cells analysis showed a significant difference in CYP17A1 mRNA expression after 24 hours of treatment (Figure 2F). Similarly, mRNA levels for STAR, HSD3B2 and CYP11A1 tended to increase, but were not statistically different, in LH, insulin and Ang II treated groups in comparison to control groups (Figure 2C-E). Even during follicular deviation in the preovulatory period, Ang II seems not to affect mRNA expression of CYP17A1 in bovine theca cells. Indeed, the intrafollicular injection of saralasin in the dominant follicle did not reduce CYP17A1 expression, which is in agreement with findings in the present study showing that Ang II do not increase CYP17A1 mRNA expression in LHtreated cells.

In the third experiment, the use of an antagonist of Ang II receptors in LH, insulin and Ang II-treated cells did not reduce androstenedione and testosterone production (Figure 3A-B). Similarly, there was no effect on mRNA expression for

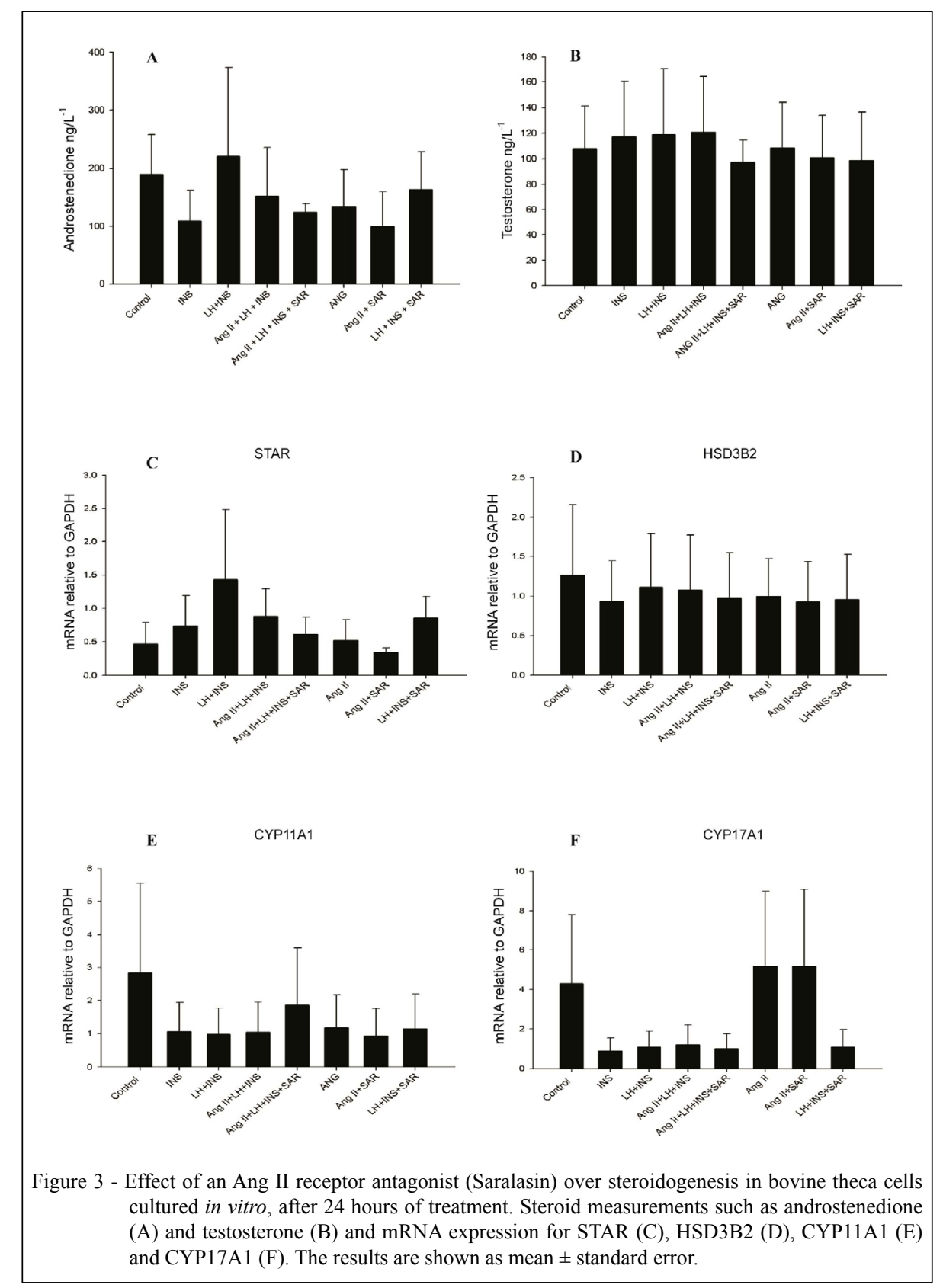

Ciência Rural, v.45, n.4, abr, 2015. 
STAR (Figure 3C) and the steroidogenic enzymes HDS3B2 (Figure 3D), CYP11A1 (Figure 3E) and CYP17A1 (Figure 3F) between different treatments. These results suggest that Ang II does not regulate steroidogenesis in bovine theca cells during the preovulatory period, such as in follicular deviation, as first shown by FERREIRA et al. (2011a) in bovine theca cells treat with saralasin. However, variances in the experimental conditions, such as the reproductive status and metabolism of the cows used for cell collection, might have accounted for the nonhomogenous findings.

In summary, findings from the present study suggest that Ang II do not regulate steroidogenesis in theca cells, as evidenced by mRNA levels of genes encoding steroidogenic enzymes, as well as, steroid hormones production. Although a significant decrease had been observed in CYP17A1 mRNA levels in treated cells compared to the control samples, there was no increase in androgen levels in response to Ang II or a decrease in response to saralasin treatment. Besides of it well-characterized roles and importance for oocyte maturation, ovulation and follicular dynamics, Ang II seems not to influence the production of androgens by in vitro theca cells.

\section{CONCLUSION}

Ang II alone or in association with LH do not stimulates steroidogenesis in bovine theca cells culture in vitro, at least under the conditions used in this study.

\section{ACKNOWLEDGMENTS}

The authors would like to thanks Frigorífico Silva for the donation of bovine ovaries used in this research and to Coordenação de Aperfeiçoamento de Pessoal de Nível Superior (CAPES), Conselho Nacional de Desenvolvimento Científico e Tecnológico $(\mathrm{CNPq})$ and Fundação de Amparo à Pesquisa do Estado do Rio Grande do Sul (FAPERGS) for financial support.

\section{REFERENCES}

COMIM, F.V. et al. Adiponectin and its receptors in the ovary: further evidence for a link between obesity and hyperandrogenism in polycystic ovary syndrome. PLoS One, v.8, n.11, p.e80416. 2013. Available from: < http://www.ncbi.nlm. nih.gov/pubmed/24260388\%3E >. Accessed: Jan. 15, 2014. doi: 10.1371/journal.pone.0080416.

FERAL, C. et al. Angiotensin II modulates steroidogenesis in granulosa and theca in the rabbit ovary: its possible involvement in atresia. Eur J Endocrinol, v.133, n.6, p.747-
753, 1995. Available from: <http://www.ncbi.nlm.nih.gov/ pubmed/8548062\%3E>. Accessed: Dec. 10, 2013.

FERREIRA, R. et al. Angiotensin II signaling promotes follicle growth and dominance in cattle. Endocrinology, v.152, n.12, p.4957-4965, 2011a. Available from: <http://www.ncbi.nlm.nih. gov/pubmed/22009728\%3E >. Accessed: Nov. 13, 2013 . doi: 10.1210/en.2011-1146.

FERREIRA, R. et al. Angiotensin II profile and mRNA encoding RAS proteins during bovine follicular wave. J Renin Angiotensin Aldosterone Syst, v.12, n.4, p.475-482, 2011b. Available from: <http://www.ncbi.nlm.nih.gov/pubmed/21459786\%3E >. Accessed: Nov. 14, 2013. doi: 10.1177/1470320311403786.

GASPERIN, B.G. et al. FGF10 inhibits dominant follicle growth and estradiol secretion in vivo in cattle. Reproduction, v.143, n.6, p.815-823, 2012. Available from: <http://www.ncbi.nlm. nih.gov/pubmed/22457435>. Accessed: Apr. 20, 2013. doi: 10.1530/REP-11-0483.

GONCCALVES, P.B. et al. Role of angiotensin in ovarian follicular development and ovulation in mammals: a review of recent advances. Reproduction, v.143, n.1, p.11-20, 2012. Available from: $<$ http://www.ncbi.nlm.nih.gov/pubmed/22046052\%3E $>$. Accessed: Nov. 24, 2013. doi: 10.1530/REP-11-0192.

PFAFFL, M.W. A new mathematical model for relative quantification in real-time RT-PCR. Nucleic Acids Res, v.29, n.9, p.e45, 2001. Available from: <http://www.ncbi.nlm.nih.gov/ entrez/query.fcgi?cmd $=$ Retrieve $\& \mathrm{db}=$ PubMed\&dopt $=$ Citation $\&$ li st_uids $=11328886 \% 3 \mathrm{E}>$. Accessed: May 23, 2011.

PORTELA, V.M. et al. Role of angiotensin II in the periovulatory epidermal growth factor-like cascade in bovine granulosa cells in vitro. Biol Reprod, v.85, n.6, p.1167-1174, 2011. Available from: $<$ http://www.ncbi.nlm.nih.gov/pubmed/21849708\%3E $>$. Accessed: Dec. 15, 2013. doi: 10.1095/biolreprod.111.094193.

SCHREIBER, N.B. et al. Expression and effect of fibroblast growth factor 9 in bovine theca cells. J Endocrinol, v.215, n.1, p.167-175, 2012. Available from: <http://www.ncbi.nlm.nih.gov/ pubmed $/ 22872763 \% 3 \mathrm{E}>$. Accessed: Nov. 10, 2013. doi: $10.1530 /$ JOE-12-0293.

SIQUEIRA, L.C. et al. Preovulatory changes in the angiotensin II system in bovine follicles. Reprod Fertil Dev, v.25, n.3, p.539-546, 2012. Available from: <http://www.ncbi.nlm.nih.gov/ pubmed/23464501>. Accessed: Oct. 28, 2013. doi: 10.1071/ RD11316 RD11316 [pii].

STEWART, R.E. et al. Effects of insulin-like growth factor I and insulin on proliferation and on basal and luteinizing hormoneinduced steroidogenesis of bovine thecal cells: involvement of glucose and receptors for insulin-like growth factor I and luteinizing hormone. J Anim Sci, v.73, n.12, p.3719-3731, 1995. Available from: $<$ http://www.ncbi.nlm.nih.gov/pubmed/8655449>. Accessed: Oct. 28, 2010.

YOUNG, J.M.; MCNEILLY, A.S. Theca: the forgotten cell of the ovarian follicle. Reproduction, v.140, n.4, p.489504, 2010. Available from: <http://www.ncbi.nlm.nih.gov/ pubmed/20628033>. Accessed: Oct. 28, 2010. doi: 10.1530/REP10-0094. 